\title{
ВЛИЯНИЕ СЕЛАНКА НА МОРФОЛОГИЧЕСКОЕ СОСТОЯНИЕ ГЕПАТОЦИТОВ КРЫС ПРИ ОСТРОМ ИММОБИЛИЗАЦИОННОМ СТРЕССЕ
}

\author{
(С Фоменко Е.В. ${ }^{1}$, Иванов А.В. ${ }^{1,3}$, Бобынцев И.И. ${ }^{2,3}$, Белых А.Е. ${ }^{2,3}$, \\ Гарбелотто Н.К. ${ }^{1}$, Андреева Л.А. ${ }^{4}$, Мясоедов Н.Ф. ${ }^{4}$
}

\author{
${ }^{1}$ Кафедра гистологии, эмбриологии, цитологии, ${ }^{2}$ кафедра патофизиологии, ${ }^{3}$ НИИ общей патологии \\ Курского государственного медицинского университета, Курск; \\ ${ }^{4}$ Отдел химии физиологически активных веществ \\ Института молекулярной генетики Российской академии наук, Москва
}

E-mail: bobig@mail.ru

Исследовано влияние внутрибрюшинного введения селанка в дозах 100, 300, 1000 мкг/кг крысам-самцам Вистар за 15 мин до начала острого иммобилизационного стресса на морфологическое состояние печени. Установлено, что острый иммобилизационный стресс вызывает изменения, более выраженные в периферическом отделе дольки, проявляющиеся развитием гидропической дистрофии, перестройкой нуклеарного аппарата, которая выражается увеличением числа ядрышек и уменьшением площади гепатоцитов за счет цитоплазмы. При введении селанка выраженность дистрофических изменений в гепатоцитах снижается, при этом увеличение дозы ведет к большей коррекции дистрофических изменений. Применение селанка в дозах 100 и 1000 мкг/кг увеличивало долю одноядрышковых гепатоцитов периферического и центрального отдела дольки. Введение селанка в дозе 300 мкг/кг повышало площадь гепатоцитов за счет цитоплазмы в периферическом и центральном отделах дольки.

Ключевые слова: селанк, иммобилизационный стресс, печень, гепатоциты, дистрофия печени.

\section{SELANK INFLUENCE ON MORPHOLOGICAL STATE OF RAT HEPATOCYTES UNDER ACUTE RESTRAINT STRESS \\ Fomenko E.V. ${ }^{1}$, Ivanov A.V. ${ }^{1,3}$, Bobyntsev I.I..$^{2,3}$, Belykh A.E. ${ }^{2,3}$, Garbelotto N.K. ${ }^{1}$, Andreeva L.A. ${ }^{4}$, Myasoedov N.F. ${ }^{4}$ \\ ${ }^{1}$ Department of Histology, Cytology, Embryology, ${ }^{2}$ Department of Pathophysiology,}

${ }^{3}$ Researc Institute of General Pathology of Kursk State Medical University, Kursk; ${ }^{4}$ Department of Chemistry

of Physiologically Active Substances of Institute of Molecular Genetics of Russian Academy of Science, Moscow

We studied effects of Selank on morphological state of liver tissue in Wistar male rats exposed to acute restraint stress. Selank was administrated by intraperitoneal injections of 100, 300 and 1,000 $\mu \mathrm{g} / \mathrm{kg} 15$ min before stress onset. We discovered that acute restraint stress led to the development of hydropic degenetation of hepatocytes, growing percentage of hepatocytes with one nucleolus, reduction in hepatocyte area due to reducing cytoplasm. The changes above-mentioned were more prominent in peripheral zone of liver lobule. Selank showed ameliorative effect on hydropic degeneration in a dose-dependent manner. The administration of 100 and $1,000 \mu \mathrm{g} / \mathrm{kg}$ Selank increased the percentage of hepatocytes with one nucleolus in peripheral and central zones of liver lobule. Peptide application in a dose of $300 \mu \mathrm{g} / \mathrm{kg}$ resulted in the growth of hepatocyte area due to increasing cytoplasm in peripheral and central zones of liver lobule.

Keywords: Selank, restraint stress, liver, hepatocytes, hydropic degeneration.

В настоящее время в многочисленных исследованиях представлены данные о повреждающем действии стресса на состояние организма, в том числе на ткань печени. Так, показано влияние стресса на развитие гидропической дистрофии гепатоцитов и воспалительной инфильтрации печеночной дольки [14]. В частности, гипокинезия запускает каскад реакций, включающий активацию клеток Купфера [9, 19], увеличение продукции активных форм кислорода и дисбаланс компонентов антиокислительной системы гепатоцитов $[8,11,15]$, приводящий к пероксидации липидов, повреждению белковых молекул и ДНК [16], набуханию митохондрий и увеличению числа аутофагосом [10].

При этом необходимо отметить, что эмоционально-негативная оценка стрессорного воздей- ствия усиливает выраженность стрессовой реакции [6]. В связи с этим при поиске способов фармакологической коррекции стресс-индуцированных сдвигов в печени целесообразно исследовать возможности использования нейротропных препаратов на основе регуляторных пептидов, к числу которых относится селанк. Регуляторные пептиды характеризуются высокой полифункциональной биологической активностью и, в отличие от целого ряда анксиолитиков и антидепрессантов, не обладают гепатотоксичностью. Известно, что селанк обладает выраженными антидепрессантными и анксиолитическими эффектами, снижает ульцерогенное действие стресса, принимает участие в регуляции воспалительной реакции и нормализует процессы свободнорадикального окисления в печени $[1,2,4,5]$, что и обусловило 
выбор его для исследования как препарата, потенциально лимитирующего повреждающее действие стресса на гепатоциты.

На основании вышеизложенного целью данной работы являлось изучение влияния селанка на морфологическое состояния паренхимы печени крыс на фоне моделирования острого иммобилизационного стресса.

\section{МАТЕРИАЛЫ И МЕТОДЫ ИССЛЕДОВАНИЙ}

Эксперименты выполнены на 50 крысахсамцах Вистар массой 250-280 г, разделенных на группы по 10 животных, которые содержались в стандартных условиях вивария и получали гранулированный корм и воду в свободном доступе при световом режиме «12 часов света - 12 часов темноты».

В работе использовали гептапептид селанк (Thr-Lys-Pro-Arg-Pro-Gly-Pro), синтезированный в Федеральном государственном бюджетном учреждении науки «Институт молекулярной генетики Российской академии наук». Селанк растворяли в физиологическом растворе и вводили внутрибрюшинно за 15 мин до начала стрессорного воздействия в дозах 100, 300 и 1000 мкг/кг. Контрольным животным вводили эквивалентные объемы физиологического раствора из расчета 1 мл на 1 кг массы тела.

Острый иммобилизационный стресс создавали путем помещения крыс в тесные индивидуальные пластиковые боксы в течение 4 часов. По окончании иммобилизации животных выводили из эксперимента обескровливанием под эфирным наркозом путем забора крови из правого желудочка сердца.

Состояние гепатоцитов и распределение поражения в отделах печеночной дольки оценивали по микрофотографиям парафиновых срезов толщиной 5-7 мкм, окрашенных гематоксилином и эозином. Основная часть морфометрического исследования была проведена после создания электронной галереи изображений с помощью полуавтоматического сканера Mirax Desk (Carl Zeiss Microimaging GMbH, Германия). С помощью программы для просмотра сканированных изображений PannoramicViewer 1.15.4 (3DHISTECH ltd, Венгрия) оценивали площади гепатоцитов и их ядер, также производили расчет площади цитоплазмы и ядерно-цитоплазматического отношения (ЯЦО). Подсчет одно- и двухъядерных, однои многоядрышковых гепатоцитов в центральном и периферическом отделах дольки проводили с помощью пакета программ ImageJ.

Достоверность полученных результатов определяли с помощью t-критерия Стьюдента и кри- терия Манна-Уитни в зависимости от типа распределения признаков и при сравнении генеральных дисперсий в сравниваемых группах.

\section{РЕЗУЛЬТАТЫ ИССЛЕДОВАНИЯ И ИХ ОБСУЖДЕНИЕ}

При гистологическом исследования препаратов печени стрессированных животных наблюдались признаки гидропической дистрофии и внутриклеточного гиалиноза гепатоцитов, воспалительной инфильтрации, более выраженные в периферических отделах. Кроме того, в промежуточных отделах дольки выявлялись зоны фокального некроза гепатоцитов (рис. 1) Острый иммобилизационный стресс не вызывал значимых изменений соотношений одно- и многоядерных гепатоцитов как в периферическом, так и в центральном отделах печеночной дольки (табл. 1). Однако в периферическом отделе дольки было выявлено достоверное снижение доли одноядрышковых гепатоцитов до уровня $1,7 \%(\mathrm{p}<0,05)$. Острый иммобилизационный стресс оказывал значимое влияние на кариоцитоплазматические показатели перипортальных гепатоцитов (табл. 2). Так, в контрольной группе по сравнению с интактными животными отмечалось снижение площади гепатоцитов периферической зоны на 5,7\% $(\mathrm{p}<0,01)$ в основном за счет снижения площади цитоплазмы на 9,3\% (p<0,01) на фоне увеличения площади ядра на $10 \%(\mathrm{p}<0,01)$ и, как следствие, возрастание ЯЦО на $18 \%(\mathrm{p}<0,01)$. Необходимо отметить, что изменения в гепатоцитах центрального отдела имели противоположную направленность: отмечался рост площади гепатоцитов на $2,6 \%$ и площади цитоплазмы на $3,2 \%$, однако изменения не достигли достоверных значений.

Применение селанка оказывало корригирующий эффект на морфофунциональное состояние гепатоцитов, проявляющееся снижением выраженности белковой дистрофии и уменьшением числа некротизированных клеток и воспалительной инфильтрации. При этом степень снижения дистрофических изменений отличалась при различных дозах селанка (рис. 2). Так, при ведении селанка в дозе 300 мг/кг снижалась выраженность дистрофии, однако отмечались разнокалиберные вакуоли как в центральном, так и в периферическом отделах дольки. Применение селанка в дозе 100 мг/кг оказывало больший корригирующий эффект. При этом отмечались лишь остаточные явления дистрофии в виде зернистости цитоплазмы преимущественно в периферическом отделе дольки. При увеличении дозы до 1000 мг/кг признаки белковой дистрофии практически отсутствовали, однако в периферических отделах сохраняется незначительная моноцитарная инфильтрация. 


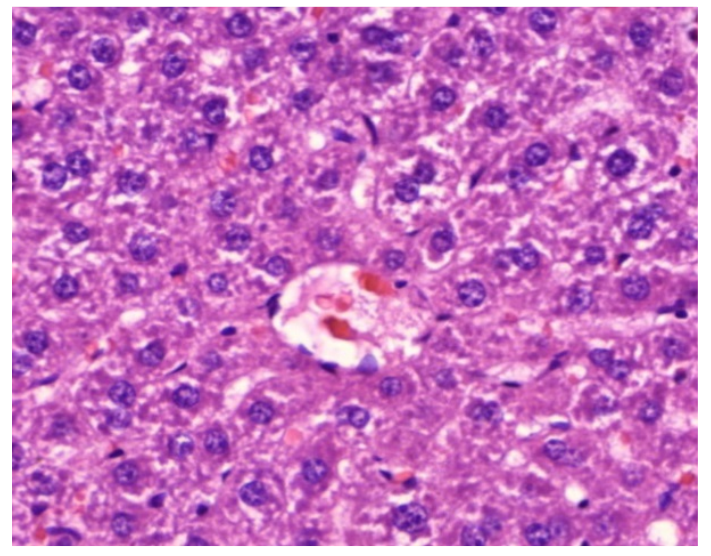

A.

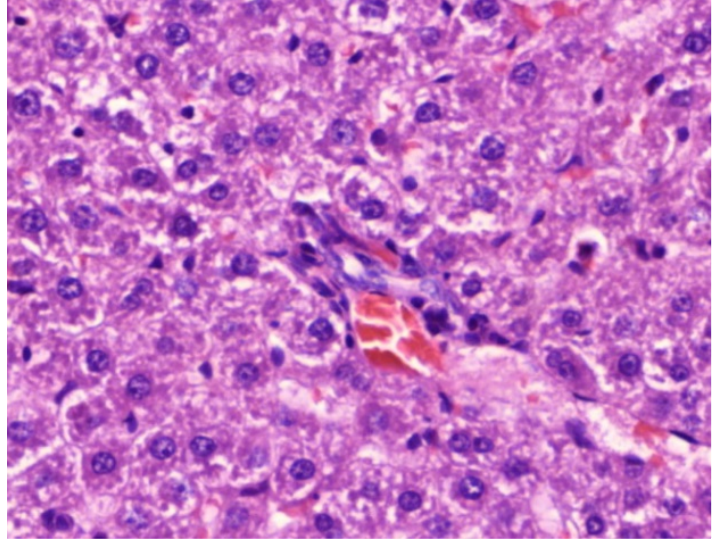

Б.

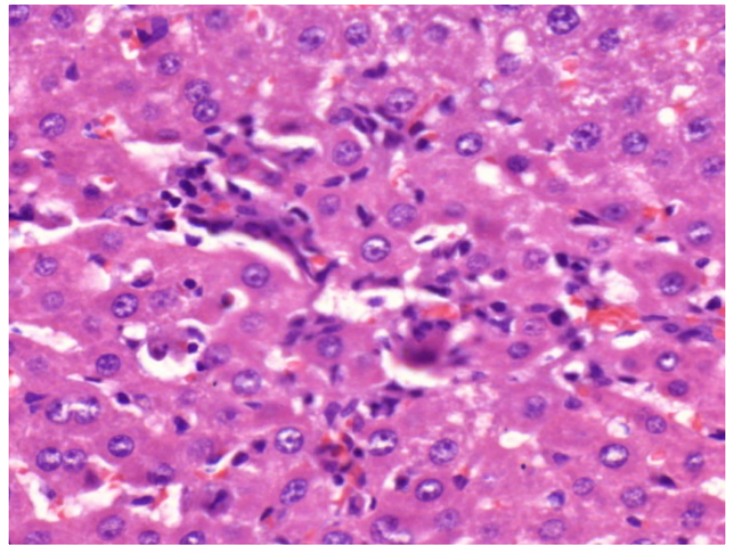

B.

Рис. 1. Состояние гепатоцитов в центральном (а) и периферическом (Б) отделах печеночной дольки, фокальные некрозы гепатоцитов (в) после моделирования острого иммобилизационного стресса на фоне введения физраствора. Окраска гематоксилин-эозином. Ув. х100.

Таблица 1

Соотношение одно- и многоядерных, одно- и многоядрышковых гепатоцитов периферического и центрального отдела печеночной дольки после моделирования острого иммобилизационного стресса на фоне введения селанка ( $\pm \mathrm{m})$

\begin{tabular}{|c|c|c|c|c|c|}
\hline \multirow[t]{3}{*}{ Группа } & \multirow{3}{*}{$\begin{array}{l}\text { Интактные } \\
\text { животные }\end{array}$} & \multicolumn{4}{|c|}{ Действие стресса } \\
\hline & & \multirow{2}{*}{ Контроль } & \multicolumn{3}{|c|}{ Введение селанка в дозе: } \\
\hline & & & 100 мкг/кг & 300 мкг/кг & 1000 мкг/кг \\
\hline \multicolumn{6}{|c|}{ Процентное соотношение гепатоцитов в периферическом отделе } \\
\hline одноядерные & $95,59 \pm 0,27$ & $95,27 \pm 0,25$ & $95,11 \pm 0,32$ & $95,86 \pm 0,27$ & $95,47 \pm 0,44$ \\
\hline многоядерные & $4,41 \pm 0,27$ & $4,73 \pm 0,25$ & $4,88 \pm 0,32$ & $4,14 \pm 0,27$ & $4,53 \pm 0,44$ \\
\hline одноядрышковые & $2,08 \pm 0,14$ & $1,70 \pm 0,13^{1}$ & $3,60 \pm 0,25^{*}$ & $1,56 \pm 0,15$ & $9,51 \pm 0,67 *$ \\
\hline многоядрышковые & $97,97 \pm 0,14$ & $98,30 \pm 0,13$ & $96,40 \pm 0,25^{*}$ & $98,43 \pm 0,15$ & $90,49 \pm 0,67 *$ \\
\hline \multicolumn{6}{|c|}{ Процентное соотношение гепатоцитов в центральном отделе } \\
\hline одноядерные & $94,91 \pm 0,43$ & $94,29 \pm 0,35$ & $93,86 \pm 0,30$ & $95,40 \pm 0,33 *$ & $92,90 \pm 0,72$ \\
\hline многоядерные & $5,09 \pm 0,43$ & $5,71 \pm 0,35$ & $6,14 \pm 0,30$ & $4,60 \pm 0,33^{*}$ & $7,10 \pm 0,72$ \\
\hline одноядрышковые & $1,97 \pm 0,15$ & $1,77 \pm 0,13$ & $3,03 \pm 0,21 *$ & $1,44 \pm 0,17$ & $8,29 \pm 0,52 *$ \\
\hline многоядрышковые & $98,03 \pm 0,15$ & $98,23 \pm 0,13$ & $96,97 \pm 0,21 *$ & $98,56 \pm 0,17$ & $91,71 \pm 0,52 *$ \\
\hline
\end{tabular}

Примечание: * - p<0,05-0,001 по сравнению с контрольной группой крыс, подвергавшихся стрессу; ${ }^{1}-\mathrm{p}<0,05-0,001$ по сравнению с интактными животными. 
Таблица 2

Влияние селанка на морфометрические показатели гепатоцитов в периферическом и центральном отделах печеночной дольки при моделирования острого иммобилизационного стресса $(\mathrm{M} \pm \mathrm{m})$

\begin{tabular}{|c|c|c|c|c|c|}
\hline \multirow[b]{3}{*}{ Показатель } & \multirow{3}{*}{$\begin{array}{c}\text { Интактные } \\
\text { животные }\end{array}$} & \multicolumn{4}{|c|}{ Действие стресса } \\
\hline & & \multirow{2}{*}{ Контроль } & \multicolumn{3}{|c|}{ Введение селанка в дозе: } \\
\hline & & & 100 мкг/кг & 300 мкг/кг & 1000 мКг/кг \\
\hline \multicolumn{6}{|c|}{ Периферическая зона печеночной дольки } \\
\hline Площадь гепатоцита, $\mu \mathrm{m}^{2}$ & $338,1 \pm 4,7$ & $319,8 \pm 4,3^{1}$ & $313,7 \pm 4,2$ & $345,4 \pm 5,5^{*}$ & $316,1 \pm 5,2$ \\
\hline Площадь ядра, $\mu \mathrm{m}^{2}$ & $51,6 \pm 0,72$ & $57,7 \pm 0,67^{1}$ & $57,8 \pm 0,8$ & $56,7 \pm 1,05$ & $54,5 \pm 0,78^{*}$ \\
\hline Площадь цитоплазмы, $\mu \mathrm{m}^{2}$ & $286,5 \pm 4,5$ & $262,0 \pm 4,1^{1}$ & $255,9 \pm 3,8$ & $288,7 \pm 5,3^{*}$ & $261,7 \pm 4,9$ \\
\hline ЯЦО & $0,190 \pm 0,003$ & $0,233 \pm 0,004$ & $0,234 \pm 0,003$ & $0,210 \pm 0,005^{*}$ & $0,230 \pm 0,005$ \\
\hline \multicolumn{6}{|c|}{ Центральная зона печеночной дольки } \\
\hline Площадь гепатоцита, $\mu \mathrm{m}^{2}$ & $346,5 \pm 5,8$ & $355,6 \pm 5,2$ & $333,8 \pm 5,1^{*}$ & $385,0 \pm 6,1^{*}$ & $318,5 \pm 5,4^{*}$ \\
\hline Площадь ядра, $\mu \mathrm{m}^{2}$ & $61,3 \pm 0,98$ & $60,8 \pm 0,78$ & $60,7 \pm 0,98$ & $62,8 \pm, 089$ & $55,3 \pm, 86^{*}$ \\
\hline Площадь цитоплазмы, $\mu \mathrm{m}^{2}$ & $285,1 \pm 5,3$ & $294,8 \pm 4,9$ & $273,0 \pm 4,5^{*}$ & $322,1 \pm 5,9^{*}$ & $263,1 \pm 5,0^{*}$ \\
\hline ЯЦО & $0,231 \pm 0,004$ & $0,225 \pm 0,004$ & $0,241 \pm 0,004^{*}$ & $0,211 \pm 0,004 *$ & $0,238 \pm 0,004 *$ \\
\hline
\end{tabular}

Примечание: * - p<0,05-0,001 по сравнению с контрольной группой крыс, подвергавшихся стрессу; ${ }^{1}-\mathrm{p}<0,05-0,001$ по сравнению с интактными животными.

Введение селанка также влияло на индуцированные стрессом изменения морфометрических показателей, при этом отмечался дозозависимый эффект. Введение селанка в дозе 300 мкг/кг вело к снижению доли многоядерных гепатоцитов в центральном отделе без изменения процентного соотношения одно- и многоядрышковых гепатоцитов. Также отмечалось увеличение площадей гепатоцитов как в периферическом, так и в центральном отделах на $8 \%$ и $8,2 \%$ соответственно $(\mathrm{p}<0,05)$ за счет увеличения площади цитоплазмы (соответственно на $10,2 \%$ и 9,3\%, p<0,01). Несмотря на то что применение пептида не оказывало влияния на площадь ядра гепатоцитов, отмечалось снижение ЯЦО на 9,6\% в периферическом отделе и на $6,1 \%$ в центральном $(\mathrm{p}<0,01)$.

Введение селанка в дозах 100 и 1000 мкг/кг не оказывало влияния на долю одно- и многоядерных гепатоцитов, однако достоверно увеличивало процент одноядрышковых гепатоцитов как в периферическом отделе до уровня $3,6 \%$ и $9,5 \%$ соответственно $(\mathrm{p}<0,05)$, так и в центральном отделе - до 3\% и 8,3\% соответственно $(\mathrm{p}<0,01)$. Применение пептида в данных дозах не оказывало значимого влияния на площади гепатоцитов в периферическом отделе, но вело к достоверному уменьшению площадей гепатоцитов в центральном отделе соответственно на $6,1 \%(\mathrm{p}<0,05)$ и $10,5 \%(p<0,01)$. Изменения происходили преимущественно за счет снижения площади цитоплазмы соответственно на 7,4\% и $10,7 \%(\mathrm{p}<0,01)$. Изменения площади ядер наблюдались только при введении селанка в дозе 1000 мкг/кг: отмечалось снижение их площади на 5,6\% в периферическом отделе и на $9 \%$ в центральном отделе $(\mathrm{p}<0,01)$. Описанные изменения не оказывали влияния на ЯЦО в периферическом отделе, но повышали данный показатель гепатоцитов центрального отдела соответственно на $6,7 \%$ и $5,5 \%(\mathrm{p}<0,01)$.

На основании полученных данных можно заключить, что острая иммобилизация индуцировала развитие стрессовой реакции, проявляющейся в печени развитием гидропической дистрофии, перестройкой нуклеарного аппарата за счет увеличения числа ядрышек и изменения кариоцитоплазматических показателей гепатоцитов. Данные изменения были более выраженными на периферии дольки. Введение селанка оказывало дозозависимое стресс-лимитирующее влияние на состояние гепатоцитов.

В развитии вышеуказанных изменений могла играть роль стресс-индуцированная активация гипоталамо-гипофизарно-надпочечниковой оси, проявляющаяся повышением уровня катехоламинов и глюкокортикостероидов в крови, стимуляцией катаболических процессов в тканях организма. Данные процессы также ведут к активации купферовских клеток, увеличению продукции ФНО [9] и активных форм кислорода в тканях печени, сопровождающейся пероксидацией липидов клеточных мембран [19], развитием оксидативного стресса, приводящего к образованию внутриклеточных белковых агрегатов, повреждению клетки [17] и белковой дистрофии гепатоцитов.

Усиление катаболических процессов ведет к метаболической перегрузке печени и снижению синтетической функции печени, проявляющейся снижением уровня общего белка в сыворотке крови [5]. Увеличение доли гепатоцитов с множественными ядрышками свидетельствует о реактивной перестройке нуклеарного аппарата печени, вследствие снижения синтетической активности гепатоцитов [7]. Введение селанка в дозах 100 


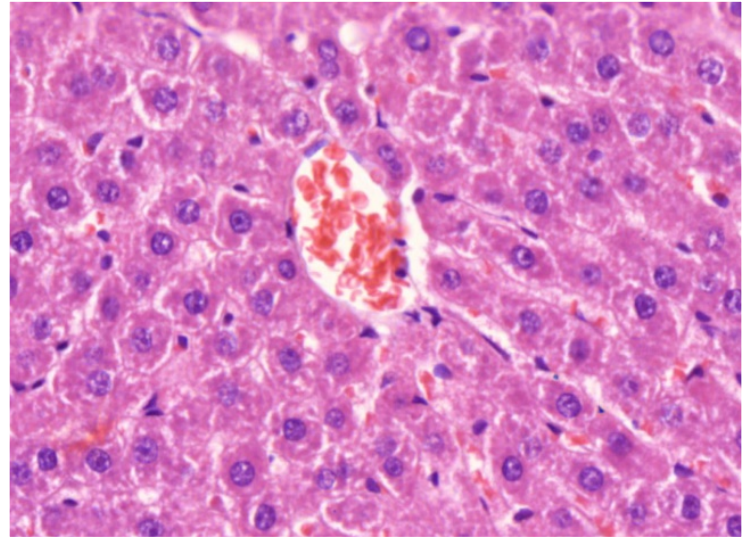

A.

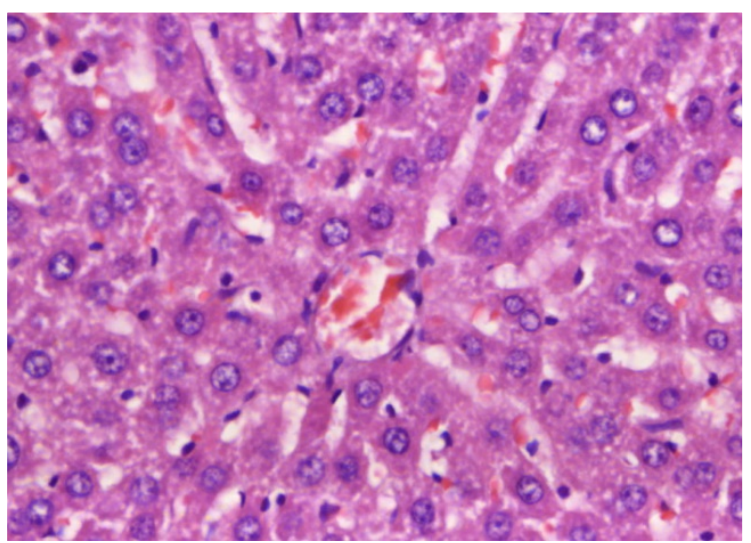

B.

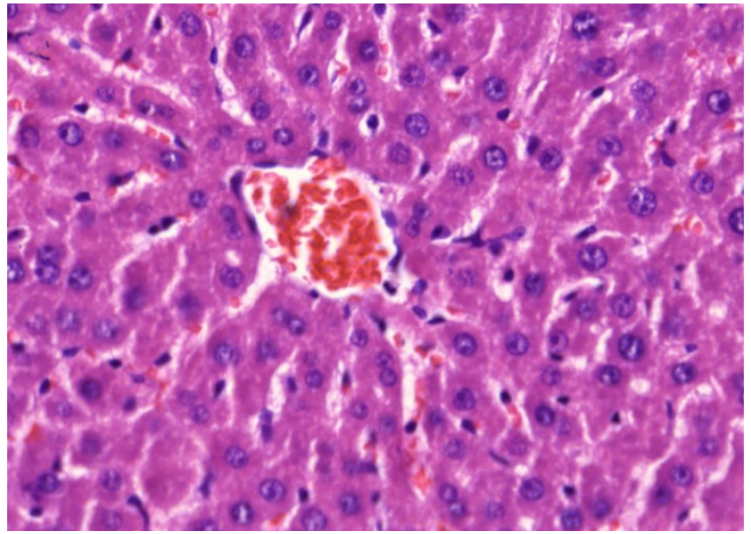

Д.

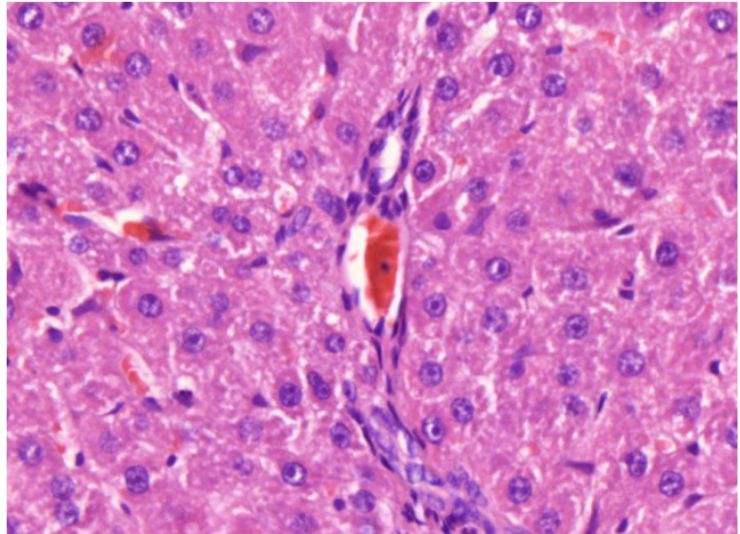

Б.

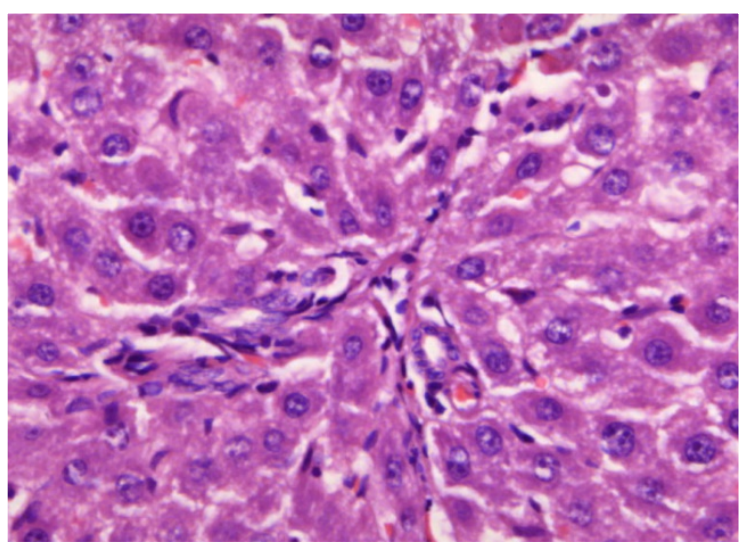

$\Gamma$.

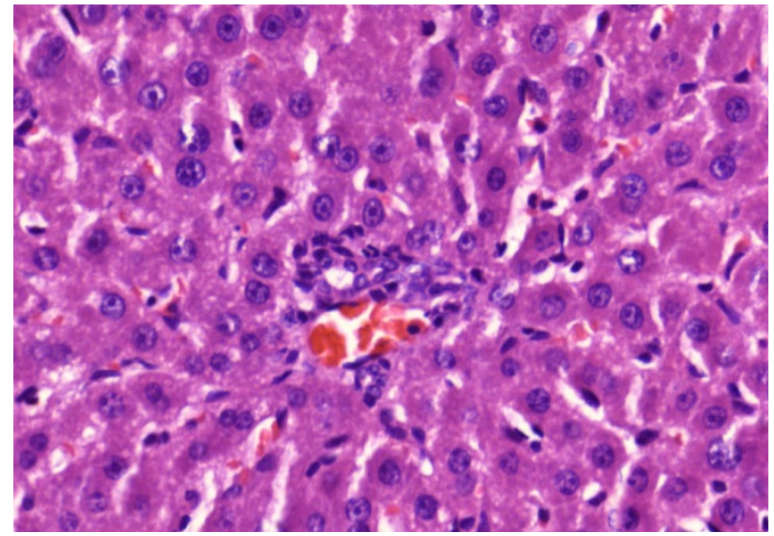

E.

Рис. 2. Морфологическое состояние гепатоцитов центральных (a, в, д) и периферических $(б$, г, е) отделов после моделирования острого иммобилизационного стресса на фоне введения селанка в дозах 100 (a, б), 300 (в, г) и 1000 (д, е) мг/кг. Окраска гематоксилин-эозином. Ув. х100.

и 1000 мкг/кг корригировало стресс-индуцированное увеличение доли многоядрышковых гепатоцитов в перипортальном отделе и увеличивало долю одноядрышковых гепатоцитов в центральном отделе дольки. Следует заметить, что введение селанка в данных дозировках также корригировало сниженный в условиях острой иммобилизации уровень общего белка в сыворотке крови крыс [5], что свидетельствует о влиянии селанка на синтетическую функцию печени и повышение ее адаптационных возможностей.
Стресс-индуцированые изменения кариоцитоплазматических показателей могут иметь следующие причины. Сокращение объема перипортальных гепатоцитов за счет цитоплазмы может развиваться вследствие усиления процессов автофагии [13]. По данным литературы, острый гипокинетический стресс, секреция глюкокортикоидов [12] и продукция активных форм кислорода [10] ведут к усилению автофагии в клетках печени, а перипортальные гепатоциты более подвержены оксидативному повреждению [18], что способствует их к большему поражению. Незначи- 
тельное увеличение площади цитоплазмы центролобулярных гепатоцитов может возникать вследствие баланса процессов автофагии и гипертрофии вследствие роста метаболической нагрузки на фоне усиления катаболических процессов. Введение селанка в дозе 300 мкг/кг вызвало увеличение объема цитоплазмы гепатоцитов как в периферическом, так и в центральном отделах печеночной дольки вследствие его корригирующего действия на процессы свободнорадикального окисления в печени [5].

Учитывая полифункциональность эффектов регуляторных пептидов, к которым относится и селанк, в основе его корригирующего действия могут находиться следующие механизмы. В частности, влияние пептида на содержание тормозных и возбуждающих аминокислот в гипоталамусе [3] вызывает анксиолитический эффект, который потенциально снижает уровень активации гипоталамо-гипофизарной оси и способствует компенсации стрессовых изменений. Однако нельзя исключать прямое регуляторное воздействие селанка на клетки Купфера и гепатоциты с учетом его влияния на экспрессию цитокинов в иммунокомпетентных клетках [2]. Однако для подтверждения данного предположения необходимо проведение дополнительных исследований, в частности, возможной рецепции пептида в культуре клеток.

Таким образом, использование селанка в условиях острого иммобилизационного стресса у крыс сопровождается гепатопротекторным эффектом за счет снижения выраженности гидропической дистрофии гепатоцитов, нормализации синтетических процессов и улучшения адаптационных возможностей печени.

\section{ЛИТЕРАТУРА}

1. Козловская М.М., Саркисова К.Ю., Козловский И.И. Влияние гептапептида селанка на депрессию поведения высоко- и низкотревожных мышей $\mathrm{BALB} / \mathrm{c}$ и $\mathrm{C} 57 \mathrm{BL} / 6$ и крыс с наследуемой депрессивностью поведения WAG/RJJ // Психофармакология и биологическая наркология. 2005. - T. 5, № 3. - C. 989-996.

2. Коломин Т.А., Шадрина М.И., Сломинский П.А., Лимборская С.А., Мясоедов Н.Ф. Изменение экспрессии генов хемокинов, цитокинов и их рецепторов под действием селанка и его фрагментов // Генетика. - 2011. - Т. 47, № 5. - С. 711-714.

3. Наркевич В.Б., Клодт П.М., Кудрин В.С., Майский А.И., Раевский К.С. Изучение эффектов гептапептида селанка на содержание моноаминов и их метаболитов в структурах мозга крыс Вистар // Психофармакология и биологическая наркология. - 2007. - Т. 7, № 2. - С. 1563-1567.

4. Павлов Т.С., Самонина Т.Е., Бакаева 3.В., Золотарев Ю.А., Гусева А.А. Селанк и его метаболиты поддерживают гомеостаз слизистой оболочки желудка // Бюл. экспер. биол. мед. - 2007. - Т. 143, № 1. - C. 57-59.

5. Фоменко Е.В., Бобынщев И.И., Крюков А.А., Иванов А.В., Андреева Л.А., Мясоедов Н.Ф. Влияние селанка на функциональное состояние гепатоцитов крыс при иммобилизационном стрессе // Бюл. экспер. биол. и мед. - 2017. - № 4. - С. 407-410.

6. Хныченко Л.К., Сапронов Н.С. Стресс и его роль в развитии патологических процессов // Обзоры по клин. фармакол. и лек. терапии. - 2003. - Т. 2, № 3. - C. 2-15.

7. Чучкова Н.Н., Кормилина Н.В., Смирнов П.В. Морфофункциональная оценка нуклеолярного аппарата гепатоцитов и лимфоцитов брыжеечных лимфоузлов крыс при измененном характере питания // Вест. Удмур. унив. «Биол. науки о Земле». - 2016. - Т. 26, № 3. - С. 98-104.

8. Bandegi A.R., Rashidy-Pour A., Vafaei A.A., Ghadrdoost $B$. Protective effects of Crocus sativus L. extract and crocin against chronic-stress induced oxidative damage of brain, liver and kidneys in rats // Adv Pharm Bull. - 2014. - Vol. 4, Suppl. 2. - P. 493499. - doi: 10.5681/apb.2014.073.

9. Chida Y., Sudo N., Kubo C. Does stress exacerbate liver diseases? // J Gastroenterol Hepatol. - 2006. Vol. 21, N 1, Pt. 2. - P. 202-208. - doi: 10.1111/j.1440-1746.2006.04110.x

10. Codogno P., Meijer A.J. Autophagy in the liver // J Hepatol. - 2013. - Vol. 59, N 2. - P. 389-391. - doi: 10.1016/j.jhep.2013.02.031.

11. Djordjevic J., Djordjevic A., Adzic M., Niciforovic A., Radojcic M.B. Chronic stress differentially affects antioxidant enzymes and modifies the acute stress response in liver of Wistar rats // Physiol. Res. - 2010. Vol. 59, N 5. - P. 729-736.

12. Epel E.S. Psychological and metabolic stress: a recipe for accelerated cellular aging? // Hormones (Athens). - 2009. - Vol. 8, N 1. - P. 7-22.

13. Hosokawa N., Hara Y., Mizushima N. Generation of cell lines with tetracycline-regulated autophagy and a role for autophagy in controlling cell size // FEBS Lett. - 2007. - Vol. 581, N 5. - P. 2623-2629. - doi: 10.1016/j.febslet.2007.05.061

14. Kim S.H., Oh D.S., Oh J.Y., Son T.G., Yuk D.Y., Jung Y.S. Silymarin Prevents Restraint Stress-Induced Acute Liver Injury by Ameliorating Oxidative Stress and Reducing Inflammatory Response // Molecules. 2016. - Vol. 21, N 4. - P. 443. - doi: 10.3390/molecules 21040443 .

15. Sahin E., Gümüşlü S. Immobilization stress in rat tissues: alterations in protein oxidation, lipid peroxidation and antioxidant defense system // Comp Biochem Physiol C Toxicol Pharmacol. - 2007. - Vol. 144, N 4. - P. 342-347. - doi: 10.1016/j.cbpc.2006.10.009.

16. Sánchez-Valle V., Chávez-Tapia N.C., Uribe M., Méndez-Sánchez N. Role of oxidative stress and molecular changes in liver fibrosis: a review // Curr Med Chem. - 2012. - Vol. 19, N 28. - P. 4850-4860.

17. Stadtman E.R., Levine R.L. Free radical-mediated oxidation of free amino acids and amino acid residues in proteins // Amino Acids. - 2003. - Vol. 25, N 3-4. P. 207-218. - doi: 10.1007/s00726-003-0011-2. 
18. Taniai H., Hines I.N., Bharwani S., Maloney R.E., Nimura Y., Gao B., Flores S.C., McCord J.M., Grisham M.B., Aw T.Y. Susceptibility of murine periportal hepatocytes to hypoxia-reoxygenation: Role for NO and Kupffer cell-derived oxidants // Hepatology. - 2004. - Vol. 39, N 6. - P. 1544-1552. - doi: 10.1002/hep. 20217.
19. Zeng T., Zhang C.L., Xiao M., Yang R., Xie K.-Q. Critical Roles of Kupffer Cells in the Pathogenesis of Alcoholic Liver Disease: From Basic Science to Clinical Trials // Front. Immunol. - 2016. - Vol. 7. P. 538. - doi: 10.3389/fimmu.2016.00538. 